\title{
Analisa Hubungan Kecerdasan Emosi dan Penyesuaian Diri Taruna Akademi Angkatan Udara Dalam Menghadapi Era Society 5.0
}

\author{
(Emotional Intelligence and Self-Adjustment Relationship \\ Analysis of Indonesian Airforce Academy Cadets in Facing the \\ Era of Society 5.0)
}

\author{
M. Hero J.A. ${ }^{1}$, Gagat Riano ${ }^{2 *}$, Aan Dedy C. ${ }^{3}$ Ismoyo $^{4}$, Limawati H. ${ }^{5}$ \\ ${ }^{1}$ Fakultas Psikologi, Universitas Gunadarma \\ E-mail: herojvnz@gmail.com \\ 2,3,4,5 Departemen Teknik Manajemen Industri, Akademi Angkatan Udara \\ E-mail:kryptonsmo@gmail.com,aandedychristiawan@gmail.com,bambang.imy@gmail.com, \\ watielimo@gmail.com
}

\begin{abstract}
Education at AAU which will be taken for four years, cadets are required to be able to adapt to the military environment, which is clearly much different from their previous world. One important factor in self-adjustment is emotional intelligence. Thus, it is necessary to conduct research on the influence of emotional intelligence on the adjustment of cadets in attending education at the AAU as part of the readiness of the AAU's role to prepare Indonesian Air Force human resources in the era of society 5.0. In this study, the method used is the correlative quantitative method to see the relationship between one or several variables with other variables. Based on the research, it was found that emotional intelligence was strongly correlated with the adjustment of $A A U$ cadets $(R=0.647$ and $R 2=0.418) . M E$ for both variables is included in the high level of category, with the ME value of emotional intelligence at 103.6974 and self-adjustment at 24.651.
\end{abstract}

Keywords-Emotional Intelligence, Self-Adjustment, Quantitative Method, Correlative Method, Society 5.0, Department of Industrial Management Engineering, Indonesia Airforce Academy.

Abstrak-Dalam pendidikan di AAU selama empat tahun, Taruna dituntut untuk mampu menyesuaikan diri dengan lingkungan militer, yang jelas jauh berbeda dengan dunia mereka sebelumnya. Salah satu faktor penting dalam penyesuaian diri adalah kecerdasan emosional. Dengan demikian sangat diperlukan adanya penelitian tentang pengaruh kecerdasan emosional terhadap penyesuaian diri Taruna dalam mengikuti pendidikan di AAU sebagai bagian dari kesiapan peran AAU untuk menyiapkan SDM TNI AU di era society 5.0. Pada penelitian ini, metode yang digunakan adalah metode kuantitatif korelatif untuk melihat hubungan antara satu atau beberapa variabel dengan variabel-variabel yang lain. Berdasarkan penelitian, didapatkan bahwa kecerdasan emosi berkorelasi kuat terhadap penyesuaian diri Taruna $A A U(R=0,647$ dan $R 2=0,418)$. ME untuk kedua variabel termasuk pada kategori tinggi, dengan nilai ME kecerdasan emosi di nilai 103,6974 dan penyesuaian diri 24,651.

Keywords- Kecerdasan Emosi, Penyesuaian Diri, Metode Kuantitatif, Metode Korelatif, Society 5.0, Departemen Teknik Manajemen Industri AAU

* Penulis Korespondensi (Gagat Riano)

E-mail:kryptonsmo@gmail.com 


\section{Pendahuluan}

$P^{\mathrm{e}}$ erkembangan teknologi dan ilmu pengetahuan yang sangat cepat memaksa manusia untuk siap menghadapi perubahan dunia termasuk di dalamnya bidang pendidikan. Salah satu bentuk perkembangan tersebut dikenal dengan istilah Society 5.0, yaitu suatu konsep yang menyatakan bahwa manusia akan dapat menyelesaikan berbagai tantangan dan permasalahan sosial dengan memanfaatkan berbagai inovasi teknologi yang lahir di era Revolusi industri 4.0 [1]. Society 5.0 sendiri pertama kali diperkenalkan oleh pemerintahan Jepang pada tahun 2019. Society 5.0 merupakan perkembangan dari revolusi industri 4.0. Revolusi industri 4.0 menggunakan kecerdasan buatan (artificial intelligence) sedangkan Society 5.0 memfokuskan kepada komponen teknologi dan kemanusiannya [2].

Pendidikan memiliki peran yang penting dalam perkembangan era Society 5.0 yaitu untuk meningkatkan kualitas Sumber Daya Manusia (SDM). Pendidikan memiliki tanggung jawab dalam memenuhi pendidikan mengenai kecakapan hidup abad 21 atau lebih dikenal dengan istilah 4C (Creativity, Critical Thinking, Communication, Collaboration). Peserta didik tidak hanya dibekali oleh ilmu pengetahuan namun juga harus dibekali dan dibiasakan dengan cara berpikir. agar nantinya terbiasa untuk bisa berpikir secara kritis, analitis, dan kreatif, serta mampu bekerja sama sebagai tim [2]

Akademi Angkatan Udara (AAU) sebagai pendidikan kedinasan militer mempunyai tanggung jawab untuk menyiapkan SDM perwira TNI AU yang diharapkan mampu mengemban tugas sebagai prajurit TNI AU serta terus dapat mengembangkan kemampuannya sejalan dengan perkembangan teknologi di era society 5.0. Hal ini telah tersirat dalam sasaran pendidikan yang ditujukan untuk membentuk Taruna yang memiliki sifat Tri Sakti Viratama, yaitu sikap dan perilaku yang dapat diandalkan (tanggon), dapat beradaptasi dengan perkembangan ilmu pengetahuan dan teknologi (Tanggap) serta tangkas dan terampil di bidang latihan jasmani dan kemiliteran (Trengginas) [3]. Untuk mencapai sasaran tersebut dibutuhkan kesiapan seluruh aspek-aspek pendidikan yang dikenal dengan 10 komponen pendidikan, salah satunya peserta didik dalam hal ini Taruna AAU.

Pendidikan di AAU selama empat tahun merupakan masa dimana Taruna dituntut untuk mampu menyesuaikan diri dengan lingkungan militer, yang jelas jauh berbeda dengan dunia mereka sebelumnya. Hal ini dikarenakan proses penyesuaian diri menjadi dasar bagi kehidupan mereka [4]. Goleman [5] mengatakan bahwa salah satu faktor penting dalam penyesuaian diri adalah kecerdasan emosional. Kecerdasan emosional berhubungan dengan persepsi, ekspresi, regulasi dan manajemen emosi, sehingga dipercaya memiliki dampak terhadap fungsi sosial dan kognitif individu [6]. Individu dengan kecerdasan emosi yang baik cenderung menunjukkan dirinya sebagai pribadi yang mudah menyesuaikan diri, hangat, tekun, gigih dan optimis [7]. Atas dasar tersebut perlu diadakan penelitian mengenai pengaruh kecerdasan emosional terhadap penyesuaian diri Taruna di dalam mengikuti pendidikan di AAU sebagai bagian dari menyiapkan SDM TNI AU di era society 5.0.

\section{LANDASAN TEORI}

Fatimah [8] menyatakan bahwa kemampuan menyesuaikan diri setiap orang berbeda-beda, tergantung dari berbagai faktor, salah satu diantaranya adalah kecerdasan emosi. Emosi merupakan salah satu karakteristik personal yang mempengaruhi penyesuaian diri seseorang terhadap bagaimana seorang individu dapat menyesuaikan diri dengan kegiatan, menyesuaikan diri dengan lingkungan, menyesuaikan diri dengan lingkup sosial pertemanan yang memiliki karakter yang berbeda-beda. Salovey dan Mayer [7] mendefinisikan kecerdasan emosi sebagai kemampuan untuk mengenali perasaan pribadi dan orang lain. Hal ini akan membantu individu dalam memahami perasaan dan maknanya, sekaligus mengendalikan perasaan, sehingga membantu perkembangan emosi, intelektual dan kemampuan dalam menentukan respon atau perilaku. Patton [9] mengartikan kecerdasan emosi sebagai kemampuan individu dalam 
menggunakan emosi secara efektif untuk mencapai suatu tujuan, membangun hubungan yang produktif, dan meraih keberhasilan di tempat kerja. Kecerdasan emosi bukanlah faktor genetik yang tidak dapat berubah, melainkan dapat disempurnakan dengan kesungguhan, kemauan, pengetahuan, dan latihan. Goleman [10] mendefinisikan kecerdasan emosi sebagai sebuah kemampuan individu untuk memotivasi diri sendiri, bertahan dalam menghadapi tekanan, mengendalikan dorongan, menunda kesenangan guna mencapai tujuan, serta mengatur suasana hati agar beban stress tidak mengganggu proses dan kemampuan kognitif. Kecerdasan emosi juga membantu individu dalam mengelola emosi pada diri sendiri dan juga saat menjalin hubungan sosial dengan orang lain. Sedangkan menurut Kosasih, Nandang dan Sumarna [11] mengungkapkan bahwa kecerdasan emosional adalah kemampuan merasakan, memahami secara efektif, menerapkan daya dan kepekaan emosi sebagai sumber energi, informasi koneksi dan pengaruh manusiawi. Berdasarkan beberapa definisi yang ada, maka dapat disimpulkan bahwa kecerdasan emosi merupakan kemampuan individu dalam memahami dan memotivasi diri sendiri, mengelola emosi diri dengan baik dan memiliki sifat empati dan memahami perasaan orang lain dalam hubungan interpersonal.

Kecerdasan emosi memiliki aspek-aspek yang akan membentuk individu menjadi lebih terampil di dalam mengenali dan mengelola emosinya. Beberapa peneliti mempunyai perbedaan pandangan tentang aspek-aspek ini. Salah satu aspek yang sering digunakan adalah seperti yang dikemukakan oleh Schutte dan Malouff [12], yaitu:

1. Persepsi terkait emosi. Kemampuan persepsi emosi yang melibatkan mengenali raut atau ekspresi wajah, isyarat suara dan kepekaan individu terhadap syarat tubuh orang lain. Hal ini jelas berhubungan dengan emosi yang individu rasakan.

2. Mengatur dan mengelola emosi diri. Kemampuan individu mengelola emosi diri sendiri, karena dengan individu dapat mengatur emosi mereka sendiri dengan baik maka akan mempengaruhi output tindakan mereka di berbagai situasi.

3. Keterampilan sosial atau mengelola emosi orang lain. Keterampilan sosial atau dapat pula disebut dengan mengelola emosi orang lain. Dimensi kedua dan ketiga dari kecerdasan emosional ini memiliki hubungan sebab-akibat. Keduanya sama-sama menjelaskan bagaimana individu dapat mengetahui sebab dan akibat dari perbedaan emosi yang ada. Dari kemampuan ini, individu akan lebih paham bagaimana harus bersikap pada situasi tertentu.

4. Memanfaatkan emosi. Kemampuan memanfaatkan efek atau dampak dari emosi, misalnya dengan mampu memanfaatkan mood positif, maka dapat mempengaruhi atau bahkan meningkatkan pemikiran kreatif seseorang

Penyesuaian diri didefinisikan sebagai sebuah proses psikososial yang dapat menjadi sumber stress dan memerlukan serangkaian ketrampilan coping (proses mengelola jarak antara tuntutan kebutuhan dengan sumber daya yang dimiliki), sehingga mampu menyesuaikan diri dalam bidang akademik, sosial, personal-emosional dan kelekatan pada institusi [4]. Hilgard dan Atkinson [13] mengatakan bahwa individu bisa dianggap memiliki kemampuan penyesuaian diri yang baik, bila mampu menyelesaikan permasalahan yang dihadapi tanpa bergantung pada mekanisme pertahanan diri, sehingga tidak menimbulkan masalah baru yang dapat mempengaruhi hidupnya. Gerungan (dalam Sunaryo [14]) mendefinisikan penyesuaian diri sebagai suatu usaha dan kemampuan individu dalam mengikuti tuntutan perubahan sosial di sekitarnya. Sedangkan Widianingsih dan Widyarini [15] mengatakan penyesuaian diri dapat diartikan sebagai kemampuan untuk mengelola konflik, kesulitan masalah hidup dan frustasi yang dihadapinya. Berdasarkan pendapat beberapa ahli diatas dapat disimpulkan bahwa penyesuaian diri adalah kemampuan yang diikuti oleh usaha seseorang untuk mengelola dan mengatasi tekanan yang muncul akibat perubahan lingkungan sosial sekitarnya, tanpa menimbulkan permasalahan baru yang dapat mempengaruhi kehidupan sosialnya.

Penelitian tentang penyesuaian diri telah banyak dilakukan, dimana salah satu tema yang sering dibahas adalah yang berhubungan dengan academic adjustment, yaitu kemampuan 
seseorang untuk menyelesaikan tuntutan atau tantangan yang berhubungan dengan aspek akademik, atau dapat diartikan sebagai proses yang dilakukan individu dalam mengelola tantangan sosial, psikologis, dan akademis, saat memasuki pendidikan tinggi [16]. Penyesuaian diri mahasiswa di perguruan tinggi sudah sejak lama dianggap sebagai hal yang penting karena dinilai berhubungan dengan tingkat keberhasilan mahasiswa dalam menyelesaikan pendidikannya di perguruan tinggi. Hal tersebut dapat dilihat oleh beberapa artikel jurnal sejak tahun 1966 yang dikutip oleh Gerdes and Mallinckrodt [17] yang membahas mengenai mahasiswa. Hal tersebut menunjukkan bahwa masalah penyesuaian diri mahasiswa di perguruan tinggi merupakan isu yang akan selalu muncul dan penting untuk dibahas, karena situasi sosial serta tuntutan jaman yang selalu berubah.

Anderson, Guan, and Koc [16] mengembangkan pengukuran terhadap academic adjustment kepada mahasiswa internasional, yaitu mahasiswa yang berkuliah di luar negaranya, yang disebut sebagai sojourner students. Skala ini disebut Academic Adjustment Scale (AAS). Mahasiswa yang mengalami perubahan lokasi tempat tinggal yang signifikan akan menemui budaya lingkungan sosial dan tuntutan akademik yang bisa jadi berbeda. Hal ini tidak bisa disamakan dengan menggunakan academic adjustment pada mahasiswa yang tidak mengalami perubahan budaya. Oleh karena itu mereka merancang pengukuran academic adjustment yang terdiri dari tiga aspek untuk dapat mengukur situasi yang dialami oleh sojourner students. Adapun ketiga aspek tersebut adalah:

1. Academic Lifestyle (gaya hidup akademik), yaitu kecocokan antara individu dan peran sementaranya sebagai mahasiswa

2. Academic Achievement, yaitu kepuasan mahasiswa terhadap performa dan kemajuan akademik.

3. Academic Motivation, yaitu dorongan mahasiswa untuk melanjutkan dan menyelesaikan perjalanan akademik mereka.

AAU merupakan institusi yang melaksanakan peran pendidikan tinggi vokasi dan pembinaan kemiliteran, untuk menyiapkan sumber daya manusia TNI AU. Pelaksanaan peran ini dilakukan secara dinamis, professional dan proposional sesuai dengan kebutuhan organisasi TNI AU. Sebagai perguruan tinggi vokasi, pelaksanaan pendidikan merujuk kepada Standar Pendidikan Tinggi Nasional (PTN) dan kurikulum berbasis KKNI (Kerangka Kualifikasi Nasional Indonesia), serta Tri Dharma Perguruan Tinggi. Falsafah program pendidikan dan pembinaan yang dilaksanakan di AAU adalah Dwi Warna Purwa Cindekia Wusana yang memiliki arti mengutamakan pembentukan kepribadian dengan jiwa kejuangan yang tinggi serta dilengkapi dengan kemampuan profesi yang mantap sebagai kebulatan. Falsafah ini bermakna bahwa pendidikan Taruna diarahkan untuk membentuk prajurit yang memiliki kepribadian dengan jiwa kejuangan dan cinta tanah air yang tinggi, serta dilengkapi dengan kemampuan akademik maupun non akademik untuk menunjang tugas dan pengabdiannya sebagai alat negara di bidang pertahanan [3].

Taruna AAU selain dibina untuk memiliki kepribadian dan mental spiritual yang kuat, juga dididik untuk memiliki kecerdasan hati dan pikiran, kemauan mengembangkan kemampuan diri, memiliki daya tangkap dan penalaran tinggi terhadap penguasaan ilmu pengetahuan dan teknologi, serta dilatih untuk memiliki kesamaptaan jasmani yang prima untuk menunjang tugas dan pengabdiannya. Hal ini tertuang dalam filsafat pendidikan dan pembinaan di AAU, Tri Sakti Viratama [3], yaitu filsafat yang mengintegrasikan tiga sifat utama keprajuritan yaitu tanggap, tanggon dan trengginas.

Visi AAU adalah menjadi perguruan tinggi militer yang unggul di bidang ilmu pengetahuan dan teknologi kedirgantaraan, serta mampu melahirkan pemimpin yang berkarakter, berintegritas, berwawasan kebangsaan, professional dan modern [3]. Untuk itu metode pendidikan di AAU dilaksanakan dengan tiga cara yang serasi, selaras, terpadu dan berkesinambungan, meliputi: 
1. Pengasuhan. Merupakan metode yang menekankan cara pembimbingan. Pengasuhan diarahkan untuk membentuk sikap perilaku taruna sebagai prajurit pejuang Saptamarga dengan titik berat aspek mental kejuangan, kepemimpinan dan wawasan kebangsaan.

2. Pembelajaran. Merupakan metode pendidikan dalam bentuk kuliah/tatap muka, belajar kelompok dan mandiri, praktek di workshop/laboratorium dan strategi pembelajaran berbasis masalah (problem based learning). Titik berat metode ini adalah aspek kecerdasan termasuk di dalamnya kemampuan manajerial dan penerapan iptek sesuai tuntutan tugas.

3. Pelatihan. Pelaksanaan metode ini ditekankan pada praktek/aplikasi lapangan, dengan sasaran utama membentuk prajurit yang trengginas melalui pemantapan pemahaman dan penguasaan pengetahuan, ketrampilan jasamani dan kemiliteran, guna mendukung pelaksanaan tugas sebagai prajurit Saptamarga. Metode ini dititik beratkan pada aspek ketrampilan/psikomotorik, kesamaptaan jasmani dan kemampuan mengaplikasikan teori dalam latihan, guna mendukung pelaksanaan tugas.

\section{Metode Penelitian}

Populasi dalam penelitian ini adalah seluruh Taruna tingkat II sampai dengan tingkat IV AAU sebanyak 345 Taruna. Sampel penelitian sebanyak 195 orang yang diambil dengan menggunakan teknik simple random sampling. Metode penelitian ini adalah metode kuantitatif korelasional. Variabel dalam penelitian ini penyesuaian diri sebagai variabel terikat dan kecerdasan emosi sebagai variabel bebas.

Pengumpulan data dilakukan dengan menggunakan dua skala, yaitu:

1. Kecerdasan emosi. Terdiri dari 33 item pertanyaan yang disusun berdasarkan empat aspek yang dikemukakan oleh Schutte dan Malouff [12], yaitu, aspek terkait emosi, aspek mengatur dan mengelola emosi diri, aspek ketraampilan sosial atau mengelola emosi orang lain dan aspek memanfaatkan emosi.

2. Penyesuaian Diri. Terdiri dari sembilan pertanyaan yang disusun berdasarkan tiga aspek Anderson, Guan, and Koc [16] yaitu Academic Lifestyle (gaya hidup akademik), Academic Achievement, dan Academic Motivation.

Kedua skala diatas disusun dengan model linkert. Item-item skala terdiri dari pernyataan favorable dan pernyataan unfavorable, dengan lima jenis sistem penilaian, yaitu Sangat Sesuai (SS), Sesuai (S), Netral (N), Tidak Sesuai (TS), dan Sangat Tidak Sesuai (STS). Setiap item pertanyaan telah melalui uji valiasi isi oleh expert judments dalam hal ini dosen Fakultas Psikologi Gunadarma. Nantinya hasil jawaban responden akan dianalisa dengan metode Product Moment dari Karl Pearson. Proses analisa data dalam penelitian ini dibantu dengan program komputer Statistical Package for Sciene (SPSS) 16.0 for windows.

\section{IMPLEMENTASI MODEL DAN PEMBAHASAN}

Berdasarkan perhitungan yang telah dilaksanakan maka didapatkan hasil sebagai berikut :

\section{A. Uji Realibilitas.}

Uji reliabilitas pada penelitian ini menggunakan reliability analysis scale (Cronbach Alpha/CA). Berdasarkan uji tersebut, nilai CA skala kecerdasan emosi sebesar 0,933 (>0,70), yang artinya mempunyai realibilitas baik. Pada skala kecerdasan emosi yang terdiri dari 33 pertanyaan, terdapat tujuh yang harus digugurkan (nilai $<0,30$ ). Sedangkan item skala 
penyesuaian diri terdiri dari enam pernyataan, ini berarti terdapat tiga item yang digugurkan. Nilai CA penyesuaian diri adalah 0,801 , menunjukkan tingkat realibilitas yang tinggi.

\section{B. Uji Normalitas.}

Uji normalitas menggunakan metode Kolmogorov-Smirnov, dimana jika nilai sig > 0,05 maka data berdistribusi normal. Hasil dapat dilihat pada tabel 1.

TABEL 1

HASIL UJI NORMALITAS

\begin{tabular}{|c|c|c|c|}
\hline VARIABEL & KOLMOGOROV SMIRNOV $(\mathrm{Z})$ & PROBABILITAS (SIG) & KETERANGAN \\
\hline Kecerdasan Emosi & 1,181 & 0,123 & Normal \\
\hline Penyesuaian Diri & 1,385 & 0,403 & Normal \\
\hline Residual & 1,027 & 0,242 & Normal \\
\hline
\end{tabular}

Berdasarkan hasil uji diperoleh nilai Kolmogorov-Smirnov 1,181 (nilai $Z$ pada $\alpha=0,05$ adalah 1,96 , Jika $Z_{\text {hitung }}<Z_{\text {tabel }}$ berarti normal)) dengan signifikansi $p=0,123(p>0,05)$ untuk variabel kecerdasan emosi dan nilai Kolmogorov-Smirnov 1,385 dengan signifikansi $\mathrm{p}=0,403(\mathrm{p}>0,05)$ untuk variabel penyesuaian diri. Hasil tersebut menunjukkan bahwa variabel penyesuaian diri dan kecerdasan emosional memiliki distribusi yang normal. Nilai Residual adalah nilai sisaan dalam hubungan lineritas kedua variabel. Dengan nilai Kolmogorov-Smirnov 1,027 dan $p=0,242$ ( $>>0,05)$, maka residual juga berdistribusi normal.

\section{Uji Linieritas.}

TABEL 2

UJI LINERITAS

\begin{tabular}{|c|c|c|c|c|c|c|c|}
\hline & & & $\begin{array}{l}\text { Sum of } \\
\text { Squares }\end{array}$ & df & Mean Square & $\mathrm{F}$ & Sig. \\
\hline \multirow[t]{5}{*}{ TOTAL_Y* TOTAL_X } & Between Groups & (Combined) & 1232.936 & 49 & 25.162 & 3.644 & 0.000 \\
\hline & & Linearity & 934.736 & 1 & 934.736 & 135.354 & 0.000 \\
\hline & & Deviation from Linearity & 298.199 & 48 & 6.212 & 0.900 & 0.657 \\
\hline & Within Groups & & 1001.351 & 145 & 6.906 & & \\
\hline & Total & & 2234.287 & 194 & & & \\
\hline
\end{tabular}

Sumber : SPSS 16

Dari hasil uji terlihat nilai $\mathrm{F}$ pada deviation from linearity adalah 0,900 , nilai ini lebih kecil dari nilai $\mathrm{F}_{\text {tabel }}(\mathrm{F} 48 ; 145=1,445)$, sehingga kecerdasan emosi memiliki hubungan linier dengan penyesuaian diri. Kelinieran ini ini juga ditunjukkan dengan tingkat signifikansi 0,657 $(>0,05)$.

\section{Uji Hipotesa.}

Pengolahan Data SPSS dapat dilihat pada tabel 3

TABEL 3

UJI HIPOTESA

\begin{tabular}{|c|c|c|c|c|c|c|}
\hline \multirow{2}{*}{\multicolumn{2}{|c|}{ Model }} & \multicolumn{2}{|c|}{ Unstandardized Coefficients } & \multirow{2}{*}{$\begin{array}{c}\text { Standardized Coefficients } \\
\text { Beta }\end{array}$} & \multirow[b]{2}{*}{$t$} & \multirow[b]{2}{*}{ Sig. } \\
\hline & & B & Std. Error & & & \\
\hline & (Constant) & 5.205 & 1.661 & & 3.134 & 0.002 \\
\hline & TOTAL_X & 0.188 & 0.016 & 0.647 & 11.782 & 0.000 \\
\hline
\end{tabular}


Hasil analisis menunjukkan besarnya koefisien korelasi antara kecerdasan emosional dan penyesuaian diri sebesar 0,647 dengan signifikansi 0,000 $(\mathrm{p}<0,05)$. Koefisien korelasi dengan nilai positif menunjukkan bahwa arah hubungan antara kecerdasan emosional dengan penyesuaian diri adalah positif. Hal ini dapat diartikan bahwa individu yang terkategori memiliki kecerdasan emosional maka individu tersebut dapat penyesuaian diri.. Persamaan garis linear berdasarkan tabel yaitu $\mathrm{Y}=5,205+0,188 \mathrm{X}$. Hal ini berarti variabel penyesuaian diri (Y) akan berubah sebesar 0,188 untuk setiap unit perubahan yang terjadi pada variabel kecerdasan emosional.

\section{E. Koefisien Determinasi.}

Dari hasil uji hipotesa didapatkan juga nilai koefisien korelasi (R) sebesar 0,647, yang artinya kecerdasan emosi memberikan pengaruh yang cukup kuat terhadap penyesuaian diri pada Taruna Akademi Angkatan Udara. Sedangkan nilai koefisien determinasi (R Square) adalah 0,418, memberikan arti bahwa kecerdasan emosi memberikan pengaruh sebesar $41,8 \%$ terhadap penyesuaian diri Taruna AAU. Hasil uji dapat dilihat pada tabel 4.

TABEL 4

KOEFISIEN DETERMINASI

\begin{tabular}{|c|c|c|c|c|c|c|c|c|c|}
\hline \multicolumn{10}{|c|}{ Model Summary } \\
\hline \multirow[b]{2}{*}{ Model } & \multirow[b]{2}{*}{$\mathrm{R}$} & \multirow[b]{2}{*}{ R Square } & \multirow[b]{2}{*}{$\begin{array}{l}\text { Adjusted R } \\
\text { Square }\end{array}$} & \multirow{2}{*}{$\begin{array}{l}\text { Std. Error } \\
\text { of the } \\
\text { Estimate }\end{array}$} & \multicolumn{5}{|c|}{ Change Statistics } \\
\hline & & & & & $\begin{array}{l}\text { R Square } \\
\text { Change }\end{array}$ & F Change & df1 & $\mathrm{df} 2$ & $\begin{array}{c}\text { Sig. F } \\
\text { Change }\end{array}$ \\
\hline 1 & $0.647^{2}$ & 0.418 & 0.415 & 2.595 & 0.418 & 138.820 & 1 & 193 & 0.000 \\
\hline
\end{tabular}

\section{F. Penghitungan Mean Empirik.}

Mean Hipotetik, dan Standar Deviasi Hipotetik. Penghitungan ini digunakan untuk menentukan penggolongan/kategorisasi hasil angket jawaban responden. Hasil penghitungan adalah sebagai berikut:

1) Kecerdasan Emosi. Pada skala kecerdasan emosi digunakan 26 pernyataan. Dengan menggunakan skala satu sampai dengan lima, maka nilai skor minimum yang diperoleh adalah $26(26 \times 1)$ dan nilai skor maksimum adalah 130 (26 x5), sehingga jarak sebaran data pada kecerdasan emosi adalah 104 (130-26). Dalam penelitian ini akan digunakan enam wilayah kurva distribusi normal (tiga daerah positif dan tiga wilayah negatif) untuk membentuk lima kategori hasil. Untuk itu nilai standar deviasi hipotek didapatkan dengan membagi jarak sebaran dengan jumlah wilayah kurva (104:6), dan didapatkan hasil 17,333. Mean hipotek (MH) didapatkan dari nilai tengah skala, yaitu 78 ( $26 \times 3)$, dan mean empirik (ME) adalah rata-rata jawaban responden, yaitu

$$
\mathrm{ME}=\frac{\sum X}{N}=\frac{20221}{195}=103,6974
$$

Dari data-data diatas dapat terlihat bahwa rata-rata Taruna AAU memiliki kecerdasan emosi yang tinggi. Periksa gambar 1.

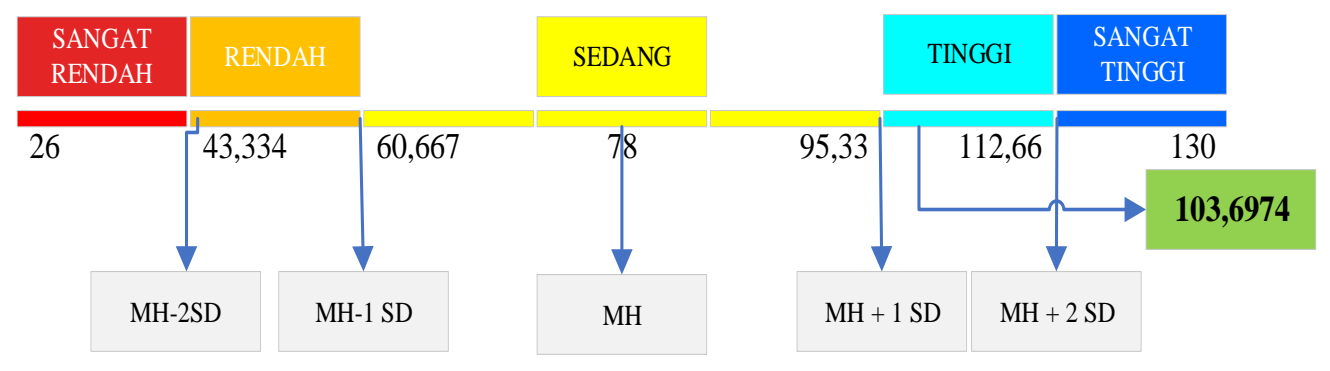

Gambar 1. Kategorisasi Kecerdasan Emosi Taruna AAU 
2) Penyesuaian Diri. Pada skala penyesuaian diri digunakan enam pernyataan. Dengan menggunakan skala satu sampai dengan lima, maka nilai skor minimum yang diperoleh adalah enam $(6 \times 1)$ dan nilai skor maksimum adalah $30(6 \times 5)$, sehingga jarak sebaran data pada kecerdasan emosi adalah 24 (30-6). Nilai standar deviasi hipotek didapatkan dengan membagi jarak sebaran dengan jumlah wilayah kurva (24:6), dan didapatkan hasil empat. Mean hipotek (MH) didapatkan dari nilai tengah skala, yaitu 18 (6 x 3), dan mean empirik (ME) adalah rata-rata jawaban responden, yaitu:

$$
M E=\frac{\sum X}{N}=\frac{4807}{195}=24,651
$$

Dari data-data diatas dapat terlihat bahwa rata-rata Taruna AAU memiliki kecerdasan emosi yang tinggi. Periksa gambar 2.

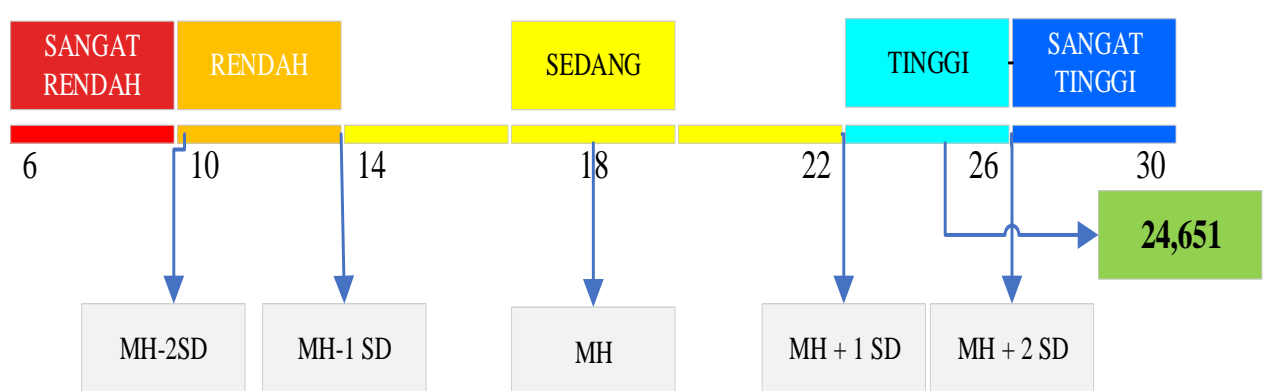

Gambar 2. Kategorisasi Penyesuaian Diri Taruna AAU

\section{G. Uji Normalitas Untuk Tiap Tingkatan.}

Berdasarkan hasil uji normalitas diperoleh nilai Kolmogorov-Smirnov dan signifikansi pada variabel penyesuaian diri dan variabel kecerdasan emosional untuk semua tingkatan menunjukkan berdistibusi normal. Hasil tersebut ditunjukkan dengan nilai Kolomogorov-Smirnov $(\mathrm{Z})$ yang lebih kecil dari nilai $Z_{\text {tabel }}(1,96)$ dan signifikansi diatas $0,05(\mathrm{p}>0,05)$.

TABEL 5

UJI NORMALITAS UNTUK TIAP TINGKAT

\begin{tabular}{|c|c|c|c|c|}
\hline \multirow{2}{*}{ TINGKAT } & VARIABEL & $\begin{array}{c}\text { KOLMOGOROV } \\
\text { SMIRNOV }(\mathrm{Z})\end{array}$ & $\begin{array}{c}\text { PROBABILITAS } \\
(\mathrm{SIG})\end{array}$ & KETERANGAN \\
\hline \multirow{3}{*}{ II } & Kecerdasan Emosi & 1,211 & 0,106 & Normal \\
\cline { 2 - 5 } & Penyesuaian Diri & 0,875 & 0,429 & Normal \\
\cline { 2 - 5 } & Residual & 0,474 & 0,978 & Normal \\
\hline \multirow{3}{*}{ III } & Kecerdasan Emosi & 0,600 & 0,864 & Normal \\
\cline { 2 - 5 } & Penyesuaian Diri & 0,787 & 0,566 & Normal \\
\cline { 2 - 5 } & Residual & 0,789 & 0,562 & Normal \\
\hline \multirow{3}{*}{ IV } & Kecerdasan Emosi & 0,733 & 0,656 & Normal \\
\cline { 2 - 5 } & Penyesuaian Diri & 1,006 & 0,263 & Normal \\
\cline { 2 - 5 } & Residual & 0,888 & 0,409 & \\
\hline
\end{tabular}

\section{H. Uji Linieritas.}

Berdasarkan hasil uji lineritas diperoleh nilai Fhitung dari Deviation from linerity dan signifikansi untuk semua tingkatan menunjukkan adanya hubungan linier antara kecerdasan emosi dengan penyesuaian diri. Hasil tersebut ditunjukkan dengan nilai Fhitung yang lebih kecil dari nilai Ftabel dan signifikansi diatas 0,05 (p>0,05). 
TABEL 6

UJI LINERITAS UNTUK TIAP TINGKAT

\begin{tabular}{|c|c|c|c|}
\hline \multirow{2}{*}{ TINGKAT } & \multicolumn{2}{|c|}{ DEVIATION FROM LINIERITY } & \multirow{2}{*}{ KETERANGAN } \\
\cline { 2 - 4 } & NILAI F $\left(\mathrm{F}_{33 ; 30}<1,823\right)$ & PROBABILITAS $($ SIG $>0,05))$ & Linier \\
\hline II & 1,325 & 0,220 & Linier \\
\hline III & 0,592 & 0,929 & Linier \\
\hline IV & 1,293 & 0,237 & \\
\hline
\end{tabular}

\section{Uji Homogenitas}

Untuk mengetahui apakah variable kecerdasan emosi dan penyesuaian diri untuk semua tingkat homogen. Hasil uji dengan SPSS adalah:

TABEL 7

UJI HOMOGENITAS UNTUK TIAP TINGKAT

\begin{tabular}{|c|c|c|c|c|}
\hline Variabel & Levene Statistic & Sig $(\mathbf{P})$ & Hasil & Keterangan \\
\hline Kecerdasan Emosi & 0,232 & 0,793 & $\mathrm{p}>0,05$ & Homogen \\
\hline Penyesuaian Diri & 1,525 & 0,220 & $\mathrm{p}>0,05$ & Homogen \\
\hline
\end{tabular}

Nilai Levene Statistic dan Signifikan untuk kedua variabel lebih besar dari 0,05. Hal ini menunjukkan varian dari tiga kelompok data tersebut adalah sama/homogen.

\section{J. Diskripsi Hasil Penelitian Berdasarkan Tingkat Pendidikan.}

Rekapitulasi hasil penelitian dapat dilihat pada tabel 8.

TABEL 8

DISKRIPSI HASIL PENELITIAN

\begin{tabular}{|l|c|c|c|c|c|c|}
\hline \multirow{2}{*}{ TINGKAT } & $\mathbf{N}$ & \multirow{2}{*}{$\begin{array}{c}\text { KECERDASAN } \\
\text { EMOSI }\end{array}$} & \multirow{2}{*}{$\begin{array}{c}\text { PENYESUAIAN } \\
\text { DIRI }\end{array}$} & \multicolumn{3}{|c|}{ UJI HIPOTESA } \\
\cline { 5 - 7 } & & 104,97 & 23,94 & 0,571 & 0,326 & $\mathrm{Y}=4,658+0,184 \mathrm{X}$ \\
\hline II & 65 & 101,57 & 24,38 & 0,747 & 0,558 & $\mathrm{Y}=2,496+0,216 \mathrm{X}$ \\
\hline III & 65 & 104,55 & 25,63 & 0,678 & 0,460 & $\mathrm{Y}=8,178+0,167 \mathrm{X}$ \\
\hline IV & 65 & &
\end{tabular}

\section{K. Pembahasan}

Pembahasan pada penelitian ini meliputi hal-hal sebagai berikut :

1) Yang menjadi responden dalam penelitian adalah Taruna AAU seluruh tingkatan (II, III dan IV) yang berjumlah 345 orang. Responden ideal untuk penelitian dengan estimasi kesalahan 0,05 dapat dihitung dengan rumus solvin sebagai berikut:

$$
\mathrm{n}=\frac{N}{N e^{2}+1}=\frac{345}{345(0,05)^{2}+1}=185
$$

Pada penelitian ini menggunakan 195 responden, sehingga memenuhi jumlah ideal penelitian.

2) Penelitian ini bertujuan untuk menguji pengaruh kecerdasan emosi terhadap penyesuaian diri pada Taruna Akademi Angkatan Udara. Berdasarkan uji hipotesa terdapat tingkat signifikan $0,000(\mathrm{P}<0,05)$. Ini menunjukkan bahwa terdapat pengaruh kecerdasan emosi terhadap penyesuaian diri Taruna. Dari uji tersebut terdapat nilai korelasi (R) sebesar 0,647. 
Angka ini menunjukkan bahwa kecerdasan emosi memiliki derajat korelasi terhadap penyesuaian diri taruna sebesar $64,7 \%$ (korelasi kuat). Sedangkan koefisien determinasi ( $R$ square) sebesar 0,418 menunjukkan bahwa kecerdasan emosi memberikan pengaruh sebesar 41,8 \% terhadap penyesuaian diri Taruna, sedangkan 58,2\% dipengaruhi faktor lain, seperti faktor fisik, faktor perkembangan kematangan diri, faktor lingkungan, faktor budaya, dan faktor agama. Penelitian ini menunjukkan hasil yang sama seperti penelitian lainnya, misal Mutammimah [18], yang meneliti tentanga hubungan positif antara konsep diri dan kecerdasan emosional dengan kemampuan penyesuaian diri dan Balluerka, Gorostiaga, Arbiol, dan Aritzeta [19], yang berhasil menemukan hubungan positif antara kecerdasan emosional dengan penyesuaian psikologis.

3) Hasil penelitian menunjukkan nilai mean empirik (ME) pada skala kecerdasan emosi Taruna AAU masuk pada kategori tinggi. Hal ini menunjukkan bahwa Taruna AAU memiliki kecerdasan emosi yang baik, dimana para Taruna mampu mengenali emosi orang lain, dapat mengelola emosi diri, mengetahui langkah atau tindakan seperti apa yang nantinya akan diambil, serta mampu memanfaatkan emosi positif yang dapat mempengaruhi atau meningkatan kreatifitas seseorang [12]. ME skala penyesuaian diri pada Taruna AAU juga termasuk dalam kategori tinggi. Hal ini menunjukkan bahwa Taruna mampu menyesuaikan dirinya dengan baik dan dapat mengikuti berbagai agenda kegiatan di AAU. Sejalan dengan penelitian yang dilakukan oleh Anderson, Guan, dan Koc [16] bahwa individu yang mampu menyesuaikan diri akan mampu menjalani peran sebagai pelajar, merasa puas atas kinerja yang didapat pada saat menempuh atau menjalani pendidikan, dan memiliki motivasi diri untuk untuk melanjutkan dan menyelesaikan pendidikannya.

4) Pada hasil perhitungan nilai ME berdasarkan tingkat pendidikan di Akademi Angkatan Udara yang didapatkan oleh peneliti menunjukkan bahwa responden untuk semua tingkatan memiliki nilai ME kecerdasan emosi dan penyesuaian diri dengan kategorisasi tinggi. Terdapat fluktuasi ME pada variabel kecerdasan emosi, dimana Taruna tingkat II memiliki ME tertinggi, diikuti tingkat IV dan tingkat III. Di sisi lain penelitian menunjukkan bahwa kecerdasan emosi pada tingkat III mempunyai korelasi yang paling besar terhadap penyesuaian diri Taruna $(74,7 \%)$, dan memberikan pengaruh yang paling besar dibandingkan tingkatan lainnya $(55,8 \%)$. Hal ini juga ditunjukkan oleh persamaan regresi, dimana satu perubahan X (kecerdasan emosi) pada tingkat III, memberikan perubahan Y (penyesuaian diri) pada Taruna $(0,216)$. Walaupun perbedaannya tidak signifikan, perlu diperhatikan beberapa faktor yang mempengaruhi kecerdasan emosi [10] yaitu kesadaran diri, motivasi diri, pengaturan diri, empati dan ketrampilan sosial. Untuk itu perlu dilakukan penelitian lanjutan yang berkaitan dengan fluktuasi nilai ME ini, sehingga dapat diketahui apakah hasil ini hanyalah temporary atau tidak. Hal ini untuk mengatasi apa yang disampaikan oleh Hurlock [20] yang menjelaskan bahwa masa remaja dianggap sebagai periode "badai dan tekanan". Suatu masa dimana ketegangan emosi meninggi sebagai akibat dari perubahan fisik dan kelenjar. Tidak semua remaja mengalami masa badai dan tekanan, namun sebagian besar remaja mengalami tidak kestabilan dari waktu ke waktu sebagai konsekuensi usaha penyesuaian diri terhadap pola perilaku baru dan harapan sosial baru. Taruna merupakan individu yang berada, dan menjalankan fase kehidupan militer yang penuh dengan aturan yang mengikat dan disiplin tinggi, yang tentu jauh berbeda dengan dunia sebelum masuk AAU.

5) ME penyesuaian diri menunjukkan peningkatan untuk tiap tingkat pendidikan. Hal ini sesuai dengan yang disampaikan oleh Syabanawati [21] yang menjelaskan bahwa individu yang mampu menyesuaikan dirinya dengan baik pada tahun pertama perkuliahan akan terus mengembangkan kemampuan yang dimiliki pada tiap semester, tingkat, atau jenjang pendidikan selanjutnya. Selanjutnya, Choirudin [22] menjelaskan bahwa dalam proses penyesuaian diri individu akan cenderung menemukan berbagai macam rintangan seperti 
terjadinya konflik, tekanan, serta frustasi yang dialami oleh individu sehingga hal ini dikhawatirkan dapat menyebabkan kegagalan individu dalam menyesuaikan dirinya. Akan tetapi, individu dengan kecerdasan emosi baik memiliki kemampuan mengenali emosi yang sedang dialami, memotivasi diri, serta dapat bertahan dalam menghadapi frustasi yang sedang dialami.

\section{KESIMPULAN}

Berdasarkan penelitian didapatkan kesimpulan bahwa kecerdasan emosi memiliki korelasi dan pengaruh yang kuat terhadap penyesuaian diri Taruna AAU ( $R=0,647$ dan $R 2=0,418)$. ME untuk kedua variabel termasuk pada kategori tinggi, dengan nilai ME kecerdasan emosi di nilai 103,6974 dan penyesuaian diri 24,651. Semuanya ini tentunya perlu mendapatkan perhatian dan bimbingan dari institusi AAU, untuk digunakan sebagai modal dalam membentuk SDM perwira TNI AU yang siap dalam menghadapi Society 5.0. Penelitian selanjutnya dilakukan untuk mengetahui pengaruh kecerdasan emosi terhadap penyesuaian diri taruna berdasarkan tingkat pendidikannya. Hasil menunjukkan bahwa ME kecerdasan emosi pada tingkat III merupakan nilai terendah dibandingkan tingkatan lainnya $(101,57)$. Hal ini perlu mendapatkan perhatian, karena dari uji yang lain menunjukkan pada tingkat III ini kecerdasan emosi mempunyai korelasi yang paling besar $(74,7 \%)$ dan juga memberikan pengaruh yang paling besar $(55,8 \%)$ terhadap penyesuaian diri.

Beberapa saran yang dapat disampaikan adalah sebagai berikut:

1. Taruna. Penelitian ini menunjukkan adanya hubungan atau korelasi yang kuat antara kecerdasan emosi dengan penyesuaian diri. Untuk itu Taruna harus terus dan mampu mengolah kecerdasan emosinya untuk membentuk pribadi yang mudah menyesuaikan diri dan lingkungan dalam menghadapi era society 5.0.

2. AAU. Hasil penelitian menunjukkan adanya hubungan yang kuat dan positif terhadap penyesuaian diri taruna untuk semua tingkatan pendidikan. Karena itu AAU sebagai institusi Pembina Taruna mampu memberikan bimbingan pengolahan emosi kepada tiap-tiap Taruna. Bimbingan tersebut dapat berupa pelatihan pengolahan emosi atau memberikan feedback positif kepada taruna yang mengalami kesulitan dalam penyesuaian diri. Feedback ini dapat dilakukan oleh dosen dan tenaga pendidikan (tanggap), pokdotar (tanggap) dan pelatih (trengginas).

3. Peneliti. Penelitian ini menggunakan skala kecerdasan emosi oleh Schutte dan Malouff (2013) dan penyesuaian diri Anderson, Guan, and Koc (2016), yang terpusat pada bidang akademi. Disarankan menggunakan skala yang berbeda untuk memperkaya informasi tentang hubungan kecerdasan emosi dan penyesuaian diri dari sudut pandang yang berbeda.

\section{UCAPAN TERIMA KASIH}

Ucapan terima kasih kami persembahkan kepada Gubernur Akademi Angkatan Udara yang telah mengijinkan terselenggaranya Seminar Nasional AAU tahun 2021. Dengan terselenggaranya seminar ini sehingga kami dapat menyusun penelitian ini dengan sebaikbaiknya. Tak lupa pula ucapan yang sama kepada seluruh panitia seminar yang telah menyusun kegiatan seminar dengan sangat apik disamping tugas-tugas pokok yang harus dikerjakan.

Selanjutnyaterima kasih juga disampaikan kepada tim penyusun penelitian. yang telah mencurahkan segenap tenaga dan pikiran untuk penelitian ini.. Kiranya masih banyak kekurangan dalam penelitian ini sehingga tim juga memohon maaf yang sebesar-besarnya. Semoga dilain waktu tim dapat menyusun kembali penelitian yang lebih mutakhir daripada yang ada saat ini. 


\section{REFERENSI}

[1] Direktorat Sekolah Dasar, "Menyiapkan Pendidik Profesional Di Era Society 5.0," 3 februari 2021, 2021.

[2] A. Sebastian S, A. S. Junior, A. Josefanny S, N. E. Kezia and S. Hendra, "Peran Pendidikan dalam Perkembangan Era Society 5.0," Jakarta, 2021.

[3] Akademi Angkatan Udara, Program Taruna Gemilang, 1 ed., Yogyakarta, 2021.

[4] R. Baker and B. Siryk, "Exploratory intervention with a scale measuring adjustment to collage," Journal of Counseling Psychology, vol. 33, no. 1, pp. 31-38, 1986.

[5] Goleman, Emotional Intelligence: Why It Can Matter More Than IQ, New York: Bantam Books, 1995.

[6] Schutte, Marlouff, Hall, Cooper, Golden and Dorheim, "Development And Validation Of a Measure of Emotional Intelligence," Personality and Individual Differences, vol. 25, pp. 167-177, 1998.

[7] P. Salovey and J. D. Mayer, "Emotional intelligence, Imagination, Cognition, and Personality," vol. 9, no. 3, pp. 185-211, 1990.

[8] E. Fatimah, "Psikologi Perkembangan," Bandung, Pusaka Setia , 2006.

[9] P. Patton, "EQ (Kecerdasan Emosional) di Tempat Kerja," Jakarta, Delapratasa, 1998.

[10] D. Goleman, "Working With Emotional Intelligence : Kecerdasan Emosi Untuk Mencapai Puncak Prestasi," Jakarta, PT Gramedia Pustaka Utama, 1999.

[11] Kosasih, Nandang and D. Sumarna, Pembelajaran Quantum dan Optimalisasi Kecerdasan, Bandung: Alfabeta, 2014.

[12] N. Schutte and J. M. Malouff, "Increasing Emotional Intelligence Through Training : Current Status and Future Direction," The International Journal Of Emotional Education, vol. 5, no. 1, pp. 56-72, 2013.

[13] E. R. Hilgard and R. C. Atkinson, Introduction to Psychology, New York: Brace and World Inc, 1967.

[14] Sunaryo, Psikologi Untuk Keperawatan, Jakarta: EGC, 2004.

[15] R. Widianingsih and N. Widyarini, "Dukungan Orang Tua dan Penyesuaian Diri pada Remaja Mantan Pengguna Narkoba," Jurnal Psikologi Universitas Gunadarma, vol. 3, no. (1), 2009.

[16] J. Anderson, Y. Guan and Y. Koc, "The Academic Adjustment Scale : Measuring The Adjustmen of Permanent Resident or Sojourner Students," Journal of Intercultural Relations, 2016.

[17] H. Gerdes and B. Mallinckrodt, "Emotional, Social and Academic Adjustment of College Students: A Longitudinal Study of Retention," Journal of Counseling and Development, vol. 72, pp. 281-288.

[18] Mutammimah, "Hubungan Konsep Diri dan Kecerdasan Emosi Dengan Kemampuan Penyesuaian Diri Pada Remaja," Jurnal Psikologi Indonesia, vol. 3, no. 1, pp. 42-51, 2014.

[19] N. Balluerka, A. Gorostiaga, I. A. Arbiol and A. Aritzeta, "Peer Attachment and Class Emotional Intelligence as Predictors of Adolescents : Psychological Wll-Being: A Multilevel Approach," Journal of Adolescence, vol. 53, pp. 1-9, 2016.

[20] E. B. Hurlock, Psikologi Perkembangan Suatu Pendekatan Sepanjang Rentang Kehidupan, 5 ed., Jakarta: PT Erlangga, 2004.

[21] E. N. Syabanawati, "Gambaran Collage Adjustment Mahasiswa Angkatan 2011 Fakultas Psikologi Universitas Padjajaran," Jurnal Psikologi Unpad, 2014.

[22] M. Choirudin, "Penyesuaian Diri Sebagai Upaya Mencapai Kesejahteraan Jiwa," Jurnal Bimbingan Konseling dan Dakwah Islam, vol. 12, no. 1, 2015. 